\title{
Valós és virtuális interaktív modellek a biológia oktatásában ${ }^{1}$
}

\author{
Nagy Melinda - Dancsa Daniel \\ - Poráčová Janka - Bernátová Renáta
}

\section{Real and Virtual Interactive Models in Biology Education Abstract}

Models have long been used in science education. The models used in the teaching process, whatever their type, always promote understanding. The aim of this work is to demonstrate the use of a real interactive model in teaching biology in upper primary school and to investigate the feasibility of further models in the teaching process. Soil erosion in education was modelled using a real interactive model. Our model was created in the courtyard of a selected Hungarian primary school in Slovakia, where a sufficient amount of sand was available for the students to build relief shapes (hill and mountain). They watered the landscapes from a watering can with a rose, observing how the irrigation water, which was used to illustrate rainwater, eroded the soil surface. The modelling was used to investigate the results of applying 'anti-erosion' solutions to the landform. This was compared with how it looks when its free, uncovered surface is washed by rainwater. Our experience shows that the children, eager to engage in the modelling, took it as a game, and learned and experienced an important ecological phenomenon through play.

Keywords: Biology education; models; soil erosion

Kulcsszavak: biológiaoktatás; modellek; talajerózió

Subject-Affiliation in New CEEOL: Social Sciences - Education - School Education

DOI: $10.36007 /$ eruedu.2021.4.5-17

\section{A modellek és a modellalkotás elmélete}

Annak ellenére, hogy régóta használnak modelleket a természettudományok oktatásában, a modellnek sokféle értelmezése van a tudományban és a közéletben egyaránt, ezért a modellezést mint iskolai tevékenységet nem egyszerű definiálni.

A modell a szakirodalom szerint a valóság kisebb-nagyobb részletének idealizált képe, de egy törvény vagy egy koncepció is lehet modell. Ugyanakkor a modelleket leghatékonyabban a rendszer müködésének a leírására, elemzésére és megmagyarázására használjuk. A modellezés tehát a megértést (a rendszer megértését) segíti elő (Chorley és Haggett 1967; Kirkby 1987; Makádi és mts. 2013).

1 A tanulmány létrejöttét a 002PU-4/2021-es számú KEGA projekt „Univerzitná výučba genetiky inovovanými formami a metódami” támogatta. 
Makádi és munkatársai (2013) szerint a modellek négy típusát különböztetjük meg:

- Statikus modellek

- Interaktív modellek

- Virtuális modellek

- Mentális modellek

A biológiatanítás elsősorban valósághelyettesitő technikaként alkalmazza a modelleket. Ezeknek korábban a leegyszerüsítés volt a meghatározó eleme és célja, valamint hogy kisebb vagy nagyobb méretben tárja a tanulók elé a természeti struktúrákat. Ez történik a statikus modellek használata során az oktatásban - amikor például az emberi szervek modellje (1. ábra), vagy egy konkrét szerv (pl. a hallócsontocskák) válnak megfoghatóvá. Ezek a statikus modellek azonban nem érzékeltetik a jelenség müködését.

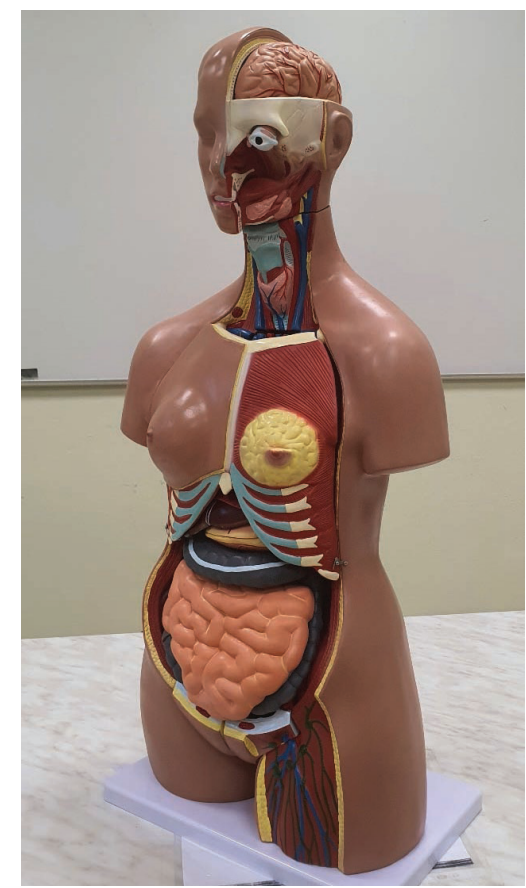

1. ábra: Statikus modell: Emberi szervek

Az interaktív modellek már müködő struktúrák, amelyek a tanuló vagy tanár aktív részvételét igénylik. A jelenség változásait vagy a jelenség részeinek egymásra való hatását tudják bemutatni, mint például pálinka előállítására alkalmas kicsinyített modell, amely elfér egy asztalon (Csémi 2014), vagy az egyetemi oktatás céljaira készült laboratóriumi sörfőző berendezés segítségével (2. ábra). A tanuló ezeknél a modelleknél tevőlegesen vesz részt a jelenség létrehozásában. 


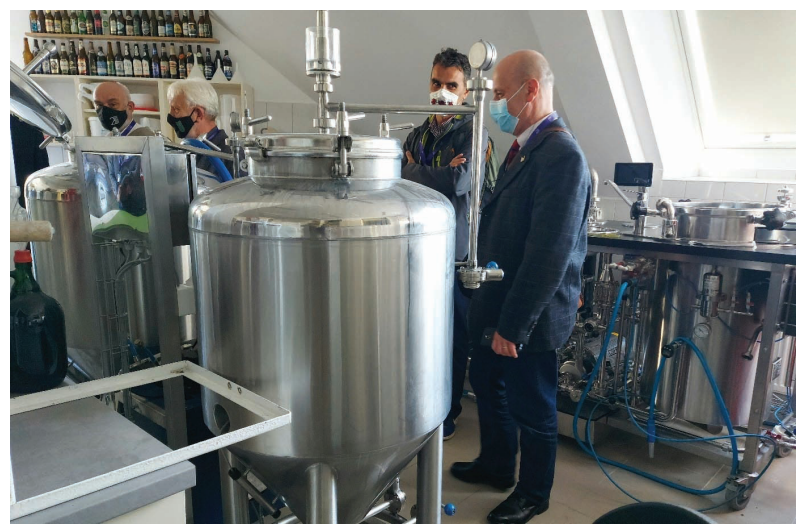

2. ábra: Interaktív modell: Sörfőző a Sapientia - EMTE Csíkszeredai Karán (fotó: Nagy M. 2021)

A virtuális modellezés elönye, hogy olyan jelenségeket is szemléltetni tudunk segítségével, amelyek a valóságban iskolai körülmények között nem lennének megfigyelhetőek. A virtuális modellek a méretüknél fogva nem befogható jelenségek szemléltetési módjai a virtuális térben - segítségükkel modellezhetünk nagyméretü komplex jelenségeket és folyamatokat, amelyek méretük vagy időtartamuk miatt nem figyelhetőek meg a valóságban teljes folyamatukban (például az üvegházhatás kialakulása - 4. ábra), vagy egészen apró, szemmel nem látható jelenségeket, például molekulákat, azok egymásra hatását, kémiai reakcióit (3. ábra) stb. (Juhász 2011, 2016; Juhász et al. 2006).

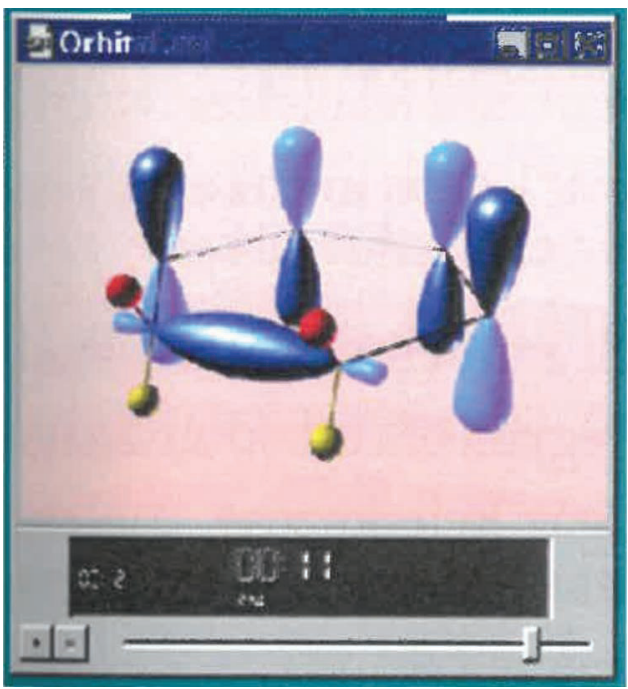

3. ábra: Virtuális modell: Az elektrociklusos reakció animációja (Juhász és Matulík 1999) 
A negyedik típusú modell, a mentális modellezés a gondolati modellek felállítását feltételezi, például amikor gondolatkísérletet végzünk, $s$ ahhoz modellezzük az idealizált külső környezeti körülményeket - például a bioritmusból adódó testhőmérséklet-változásokat 24 óra alatt, miközben a modellben kizárunk minden zavaró körülményt (a környezet hőmérsékletváltozását, a hirtelen fizikai terhelésből származó hőtermelést, a más személyekkel való konfliktusból származó stresszreakciót stb.). Ennek használata az oktatásban ritka jelenség, nemcsak az általános és középiskolában, hanem az egyetemi képzésben is.

\section{Valós és virtuális modellek a természettudományokban}

A valós modellek régóta használatosak a természettudományok oktatásában. Ezek lehetnek olyan artefaktumok, amelyeket kifejezetten oktatási céllal állítanak elő (például egy szilikon vagy modell, amelyik a szivet formálja meg), vagy olyan objektumok, amelyek természeti eredetűek (például a marokkövek a kőzettan oktatásához, vagy egy eredeti teknőspáncél).

A valós modellek hátránya, hogy annyi példányra van szükség belölük, ahány helyszínen szeretnénk őket bemutatni.

A virtuális modell ezzel szemben könnyen multiplikálható, de informatikai eszközök alkalmazását feltételezi, hiszen ezek a modellek, miközben megfelelnek a modellekkel szemben támasztott követelményeknek, egy virtuális térben jönnek létre. Az iskolák napjainkban fel vannak szerelve alapvető informatikai eszközökkel, és általában számíthatunk arra is, hogy a tanulók otthonában is megtalálhatóak azok az eszközök, amelyek a virtuális modellek megtekintéséhez szükségesek.

Ezek a modellek a virtualitást kihasználva azért nagyon jól alkalmazhatóak a közoktatásban a természettudományi tárgyak tanitására, mert általuk megszűnik minden korlátozás: egy virtuális modell képes ábrázolni egy nanorészecskét, de akár egy több millió fényév átmérőjü csillagászati objektumot is, vagy képes néhány perc alatt bemutatni több milliárd évnyi történetet, de a másodperc törtrészét is le tudja lassítani akár több perces filmre. További elöny, hogy ugyanazt a modellt számos tanuló tudja egyszerre használni anélkül, hogy ebben egymást korlátoznák.

A közoktatásban ezeket a modelleket jellemzően a természettudományi tantárgyak támogatására használják, azokból is a legelterjedtebbek a fizikaoktatásban, kémiaoktatásban, de előfordulnak a biológia- és a földrajztanításban is. Magyar nyelven is elérhető szimulációkat találunk például a University of Colorado Boulder „Interaktív szimulációk matematikához és természettudományokhoz" c. weblapján (https://phet.colorado.edu/hu/). A PhET szórakoztató, interaktív és kutatáson alapuló ingyenes szimulációkat ajánl fel fizikai jelenségekröl. Hitvallásuk szerint a kutatáson alapuló megközelítésük - amely mások korábbi eredményeit és a saját új kutatásaikat egyaránt tartalmazza - segíti a diákokat abban, hogy kapcsolatot találjanak a hétköznapi jelenségek és a mögöttes tudomány között, elmélyitve a fizikai világ megértését és értékelését. 


\section{Virtuális modellek a biológiában}

A biológiaoktatásban a virtuális modellezés leginkább animációkkal és szimulációkkal valósul meg.

A biológiatanítás számára jelenleg rendelkezésre álló animációk döntő többsége a mozgófilmet helyettesíti. Ha párhuzamot vonunk az animáció és a videofilm között, az animáció elönye, hogy azoknál élni lehet a részletek kiemelésével vagy éppen eltompításával, így a tanuló nem veszik el a sok kis részletben, azonnal láthatóvá válik, mi a fontos.

A szimulációk előnye, hogy lehetővé teszik a tanulói beavatkozást, tehát a szempontszerű vizsgálódást is - például az üvegházhatás kialakulását bemutató szimuláció esetében (4. ábra) módosithatóak bizonyos paraméterek - az üvegházhatásért felelős gázok koncentrációja, a felhők száma, illetve az antropogén eredetű objektumok száma a tájban.

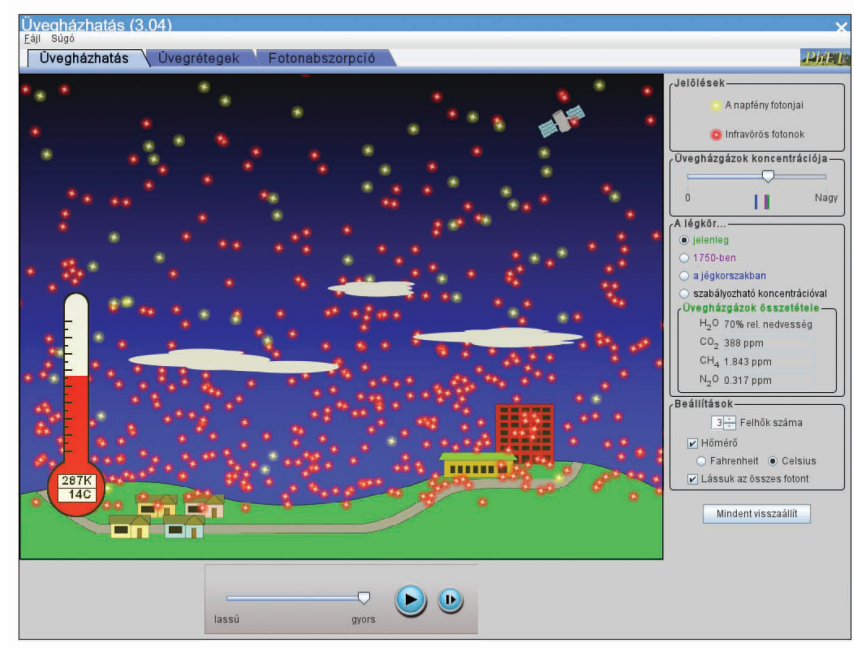

4. ábra: Az üvegházhatás folyamata (Adams et al. 2021)

\section{Célkitüzések}

A munka célja bemutatni egy valós interaktív modell felhasználását a biológiaoktatásban az alapiskola felső tagozatán, valamint megvizsgálni a további modellek felhasználhatóságát az oktatási folyamatban. 


\section{Anyag és módszerek}

Az oktatásban a talajeróziót modelleztük valós interaktív modell segítségével. A modell megalkotásának a helyszíne egy kiválasztott szlovákiai magyar alapiskola udvara volt, ahol rendelkezésre állt kellő mennyiségü homok, amelyből a tanulók domborzati formákat (hegyet és dombot) építettek (5. ábra).

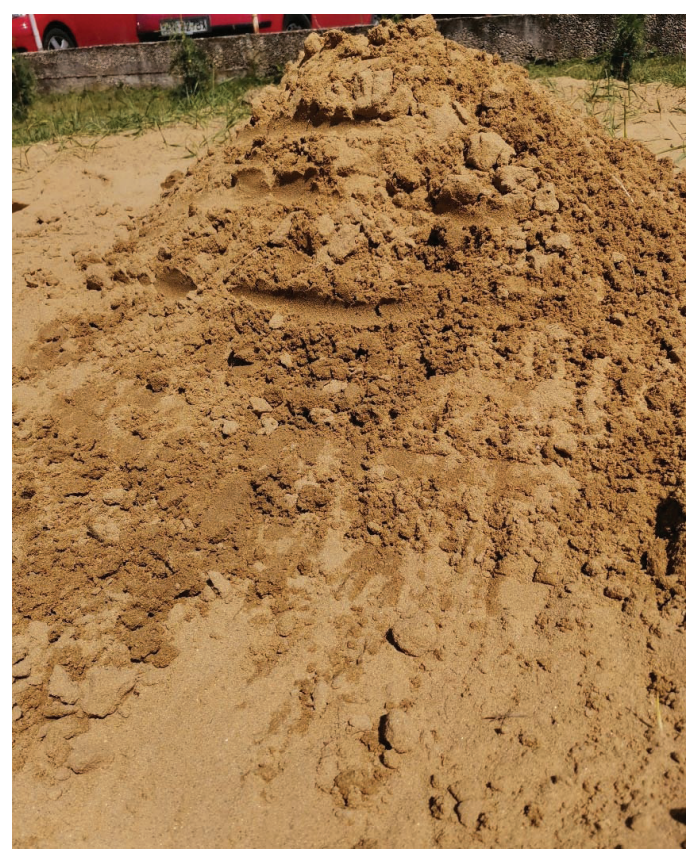

5. ábra: Homokhegy az első fázisban (fotó: Dancsa D. 2021)

\section{Valós interaktív modell alkalmazásának eredményei a bioló- giaórán}

A domborzati formákat ezután rózsával ellátott öntözőkannából vízzel locsolták (6. ábra), megfigyelve, hogyan erodálja a csapadékvizet szemléltető öntözővíz a talajfelszínt annak függvényében, milyen lejtöszöget sikerült kialakítani (7. ábra).

A domborzati formák egy részénél „eróziógátló” megoldásokat alkalmaztunk. Ilyen lehet a valóságban a növényzet gyökere, vagy más mesterséges megoldások, például az autópályák mellett gyakran alkalmazott fühálók vagy rekeszek kihelyezése, amelyek megfogják a talajt a meredek lejtőn, amíg a növényzet gyökere át nem szövi azt. Homokozói modellünkben megvizsgáltuk, milyen eredményre vezet, ha a domborzati forma felszínét fücsomókkal boritjuk, összevetve azzal, ha szabad növénytakaró nélküli felszínét mossa a csapadékvíz. 


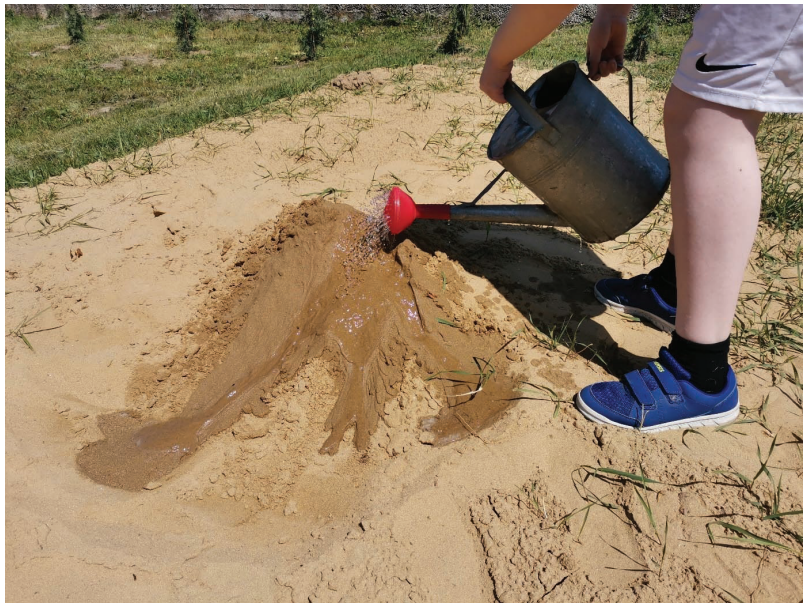

6. ábra: A homokhegy öntözése (fotó: Dancsa D. 2021)

A gyerekek nagyon szemléletesnek találták, hogy bármit tettek a felszínre (gyökérzet, szúnyogháló, géz, fásli, moha, kavics), az megakadályozta vagy csökkentette a talajeróziót a szabadon hagyott felszínhez képest (8. ábra).

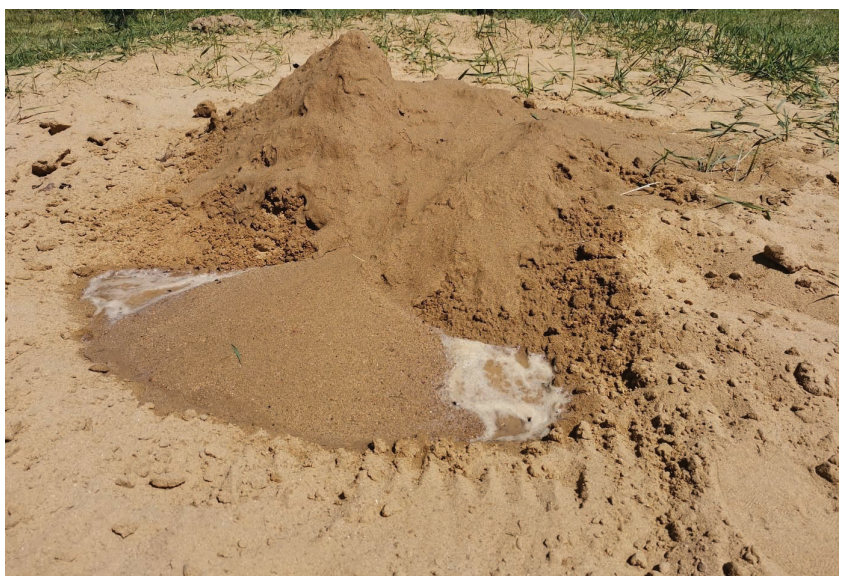

7. ábra: Eróziós folyamatok szemléltetése homokhegyen (fotó: Dancsa D. 2021)

Az eróziós valós interaktív modellnek az alkalmazása nemcsak terepen vagy udvaron lehetséges, hanem bent az osztályteremben is, homokasztal, vagy egy nagy tálca segítségével. A modell használata nem jelent nagy kihívást, az eszközök olcsón beszerezhetöek, nem is különösebben időigényes az elökészitése. A legnagyobb „veszélyt” a benti alkalmazás során az jelenti, ha a gyerekek belelendülve a modellezésbe nem ügyelnek a tisztaságra, és a homok egy része a padlóra kerül. 


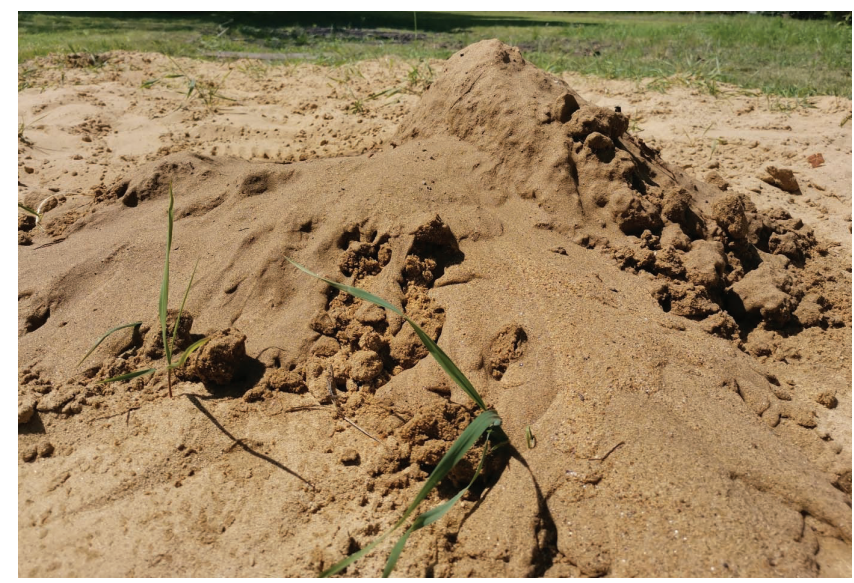

8. ábra: Eróziós folyamatok gátlásának szemléltetése (fotó: Dancsa D. 2021)

Tapasztalataink azt mutatják, hogy a gyerekek (de a tanitóképzős egyetemisták is) szivesen bekapcsolódtak a modellezésbe, játéknak vették, és játszva tanultak, szereztek tapasztalatokat egy fontos ökológia jelenséggel kapcsolatban.

\section{3D-s virtuális modellek a biológiatanításban}

A virtuális modellek speciális formáját jelentik a 3D-modellek. Ebbe a kategóriába sorolhatók azok a 3D-modellek, amelyek természeti struktúrák térbeli forgatását, különböző irányból történő megtekintését, szétszedését, összerakását, valamint különböző folyamatok tanulmányozását teszik lehetővé.

Például egy 3D rovar-modell előnye a valóssal szemben abban áll, hogy felnagyítva ábrázolja a rovart. Ha párhuzamot vonunk az animáció és a videófilm között, azok különbségeihez hasonlóan a 3D-modelleknél is élni lehet a részletek kiemelésével vagy éppen eltompításával, így a tanuló nem veszik el a sok kis részletben, azonnal láthatóvá válik, mi a fontos. Ráadásul itt a valóság lefilmezésével ellentétben lehetőség van kiemelni bizonyos jelenségeket, struktúrákat, a kevésbé fontosakat pedig elnyomni, vagy nem ábrázolni. Nem utolsó szempont az sem, hogy ezzel a módszerrel megelőzhető az élölények pusztítása is, hiszen egy rovarból készült modell sok helyen egyszerre és hosszú időn keresztül lesz használható az oktatásban.

A felvázoltakkal ellentétben azonban a talajerózió valós szemléltetése nem jár élölények pusztulásával. Viszont lehetnek helyzetek, körülmények, amikor minden elönye ellenére ez a valós eróziós modell nem lesz alkalmazható. Ilyen esetben javasoljuk az eróziót szemléltető virtuális modelleket, melyekböl több is elérhető az interneten, általában angol nyelvű változatban.

Egyik példa erre Eekhout és de Vente (2018) „SPHY-MMF - Coupled Hydrology-Soil Erosion Model"-je, amely videó formájában érhető el az online térben ( 9 . ábra). 


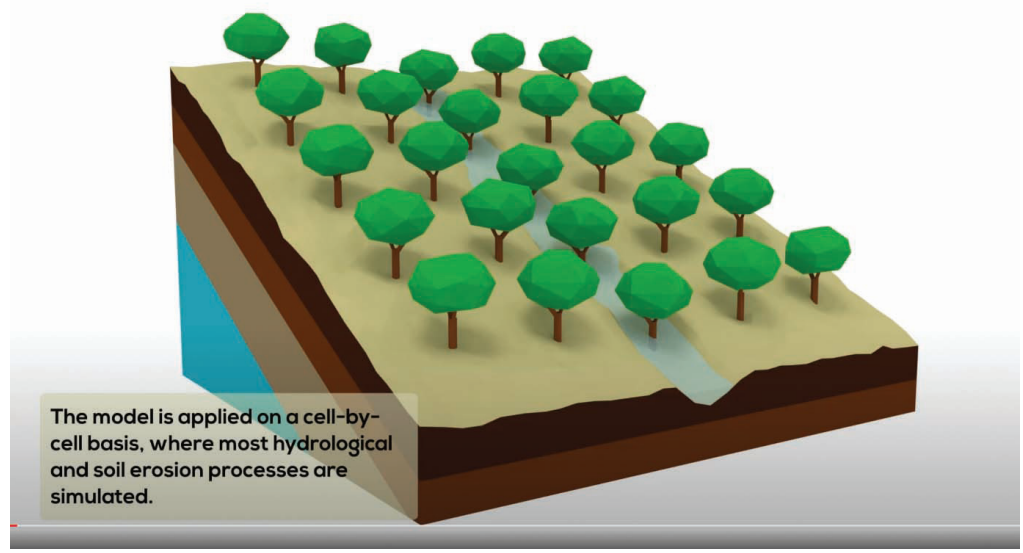

9. ábra: 3D virtuális modell a talajerózió szemléltetésére (Eekhout és Vente 2018)

\section{Megvitatás}

Az oktatás minőségének biztositása érdekében, hogy a tanítási folyamat a mindenkori elvárásokhoz és lehetőségekhez igazodjon, új módszerek és oktatási formák alkalmazására van szükség (Zahatňanská et al. 2019).

A Selye János Egyetem Tanárképző Kara Biológia Tanszéke az Eperjesi Egyetem Humán és Természettudományi Tárgyak Kara, valamint Tanítóképző Kara munkatársaival évek óta együttmüködve folytat kutatásokat a tantárgypedagógia területén, valamint a biológia és természetismeret tanitásának módszertanában. Eddigi eredményeink tudományos folyóiratokban (Bernátová et al. 2019, 2020) és tankönyvekben jelentek meg (Poráčová et al. 2014a, 2014b, 2015, 2021).

A cikkünkben említett valós és virtuális modelleken kivül is célszerü további újszerủ oktatási módszereket alkalmazni az oktatásban. Elvárható például a webes alkalmazások oktatási folyamatba történő integrálása (Czakóová 2016; Czakóová és Szőköl 2012; Puskás 2018a), az információs és kommunikációs technológiák és speciális szoftverek (Czakóová és Stoffová 2020; Kiss és Árki 2016; Puskás 2018b; Mydlár et al. 2008; Poráčová et al. 2008; Bernátová et al. 2020) használata, különösen a világjárvány miatt online megvalósuló oktatás esetén.

A motivációs stratégiák alkalmazása és a tanulók kreativitását támogató megoldások (Puskás 2017, 2019) is rendkivül fontosak ilyenkor. A tanárképzésnek feladata, hogy a leendő pedagógusokat felkészitse ezekre a kihivásokra. A tanitási módszerek és a különféle munkaformák sokszinüsége enyhíti az egyhangúságot, és az aktivizáló módszerek is effektíven növelik a tanítási folyamat hatékonyságát (Zahatňanská és Kušnírová 2017).

A talajeróziót bemutató valós interaktív modell mellett a világhálón hozzáférhetőek további virtuális modellek, amelyek előkészitése a miénknél időigényesebb lehet, de videón történő bemutatásuk jól kiegészitheti saját valós modellünk magyarázatát. Ilyen lehet például Hottenstein (2015) „Erosion and Soil” címü videója 
(10. ábra), ahol részletesen bemutatásra kerül a növényi gyökerek megkötő ereje.

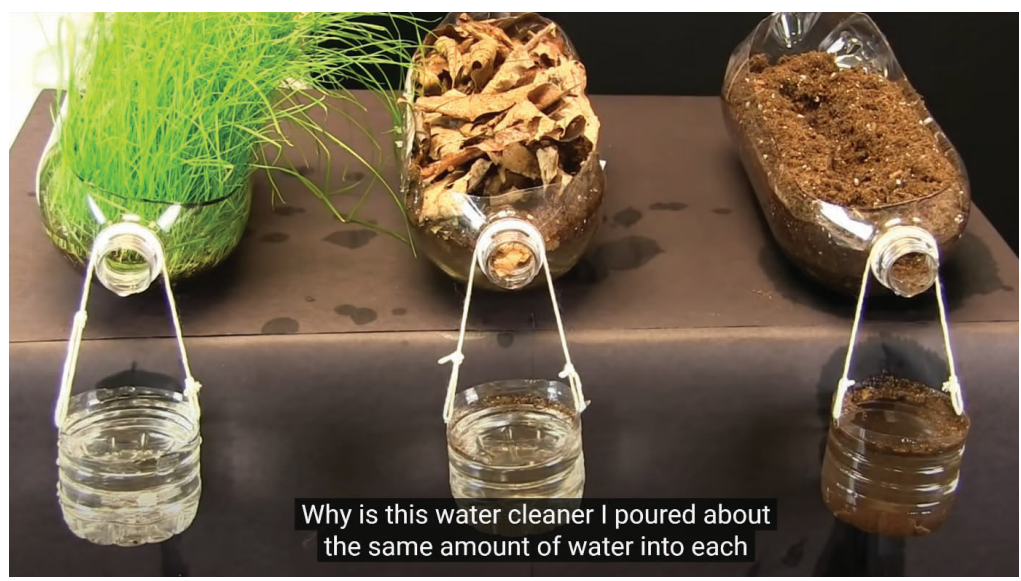

10. ábra: „Erózió és talaj” virtuális modell - Hottenstein (2015)

A Selye János Egyetem Gazdaságtudományi és Informatikai Kara Informatika Tanszékének munkatársai modellezéssel is foglalkoznak. Elsősorban a kulturális örökség artefaktumainak megörökítését célozták meg, a komáromi Lapidárium kőtárgyainak 3D-s megjelenitését, de további épületek külső és belső architektúráját is sikerrel modellezték már (Czakóová és Takáč 2020; Fröhlich et al. 2020; Gubo et al. 2020; Takáč 2017, 2020; Takáč és Végh 2021a, 2021b). Ezek a modellek felhasználhatók a biológiatanár-képzés antropológia tantárgyában, de még értékesebbek azok a tapasztalatok, melyek alapján biológiai objektumok modellezése is megvalósítható. Tervezett közös kutatásunk valószínüleg újszerüen hat majd, hiszen eddig 3D-modelleket az oktatásban elenyésző mértékben használtak. Az általunk elöállítandó modellek közelebb hozhatják a diákok számára azt a világot és annak felépítését, amelyet nem minden nap látunk. Az oktatás ismételt online keretek közé szorulása esetén pedig gyakorlatilag egyedüli eszköz lehet arra, hogy a pedagógus helyettesítse a közös terepi vagy laboratóriumi bemutatót. Várható eredményeinket valószínűleg nem csupán az oktatás üdvözölné, hiszen egy 3D-modell raktározása is sokkal könnyebb, így a szaktantermek és esetleg a múzeumok is felhasználhatják azokat. Természetesen a legnagyobb jelentőséggel az oktatásba történő beemelésük bírhat.

\section{9. Összegzés}

A tanulmány a valós és virtuális modellek alkalmazási területeit vizsgálja a biológia tanításában egy konkrét valós interaktív modellre fókuszálva, amely a talajerózió müködését modellezi: a gyerekek a homokból létrehozott domborzati formákat rózsával ellátott öntözőkannából vízzel locsolva figyelték meg, hogyan erodálja a csapadékvíz a talajfelszínt annak függvényében, milyen lejtőszöget sikerült kialakítani, 
vagy milyen eróziógátló található a felületen vagy a talajban. Tapasztalataink azt mutatják, hogy a gyerekek (de a tanítóképzős hallgatók is) szivesen bekapcsolódtak a modellezésbe, játszva tanultak, szereztek tapasztalatokat egy fontos ökológia jelenséggel kapcsolatban. Tapasztalataink alapján tovább folytatjuk a virtuális és valós modellek integrálását a biológiaoktatásba.

\section{Irodalom}

Adams, W - Blanco, J. - Lancaster, K - LeMaster, R. - Loeblein, T. - Parson, R. - Perkins, K., - Wieman, C. (2021): Üvegházhatás Verzió 3.04. PhET Interactiv simulations. University of Colorado Boulder. https://phet.colorado.edu/hu/simulations/greenhouse/credits (Letöltve 2021. május 31.).

Bernátová, R. - Bernát, M. - Poráčová, J. - Nagy, M. - Sedlák, V, - Sepešiová, M. Vadašová, B. (2019): Visualization of the logical structure of biologically and ecologically oriented curriculum and its application in teaching to increase the level of understanding of causality (Coherence of cause and effectin) in the curriculum. Journal of Science Education $=$ Revista de Educacion en Ciencias $=$ Revista de Educacion en Ciencias. Vol. 20, no. 2 (2019), p. 54-75. SCOPUS. ISSN 0124-5481.

Bernátová, R. - Bernát, M. - Poráčová, J. - Nagy, M. (2020): Teaching of the thematic unit photosynthesis in the natural sciences with didactics for teacher training programmers in primary education with the support of the interactive whiteboard. Journal of Science Education = Revista de Educacion en Ciencias. Vol. 21, no. 2 (2020), p. [1-10]. ISSN 0124-5481.

Chorley, R. J. - Haggett, P. (1967): Models in geography. London: Methuen, 816 p.

Czakóová, K. - Szököl, I. (2012): Alkalmazásfejlesztés a leendő tanítók részére Imagine programkörnyezetben. In: New technologies in research, science and education. Komárno: Univerzita J. Selyeho, 2012, p. 139-144. ISBN 978-80-8122-063-0.

Czakóová, K. (2016): Tvorba vlastných aplikácií v Imagine. In: Úvod do programovania v prostredí mikrosvetov. Komárno: Univerzita J. Selyeho, 2016, p. 34-55. ISBN 978-808122-170-5.

Czakóová K. - Stoffová V. (2020): Tanárjelöltek tanítási gyakorlatának jelenlegi kérdései, a tanárképzés digitális átalakítása. In: InfoDidact 2020: 13. Informatikai Szakmódszertani Konferencia. Budapest: Webdidaktika Alapítvány, 2020, p. 215-222. ISBN 978-61580608-4-4.

Czakóová, K. - Takáč, O. (2020): Tvorba realistického modelu v rámci obsahu predmetu stredoškolskej informatiky. In: Proceedings of 33. DidMatTEech 2020 Conference: New methods and technologies in education, research and practice : New methods and technologies in education, research and practice. Budapest: Eötvös Loránd Tudományegyetem, 2020, p. 14-21. ISBN 978-963-489-244-1.

Csémi J. (2014): A pálinka elöállítása és minőségi mutatóinak elemzése. Záródolgozat (Témavezető: Gyepes, R.). Komárom: Selye János Egyetem, Tanárképző Kar, Biológia Tanszék.

Eekhout, J. - de Vente, J. (2018): SPHY-MMF - Coupled Hydrology-Soil Erosion Model. Sep 3, 2018. https://www.youtube.com/watch?v=yP105w3VEN8 
Fröhlich R. - Kató Z. - Gubo Š. - Tamás L. - Végh L. - Takáč O. (2016): 3D-2D adatok fúziója kulturális örökségvédelmi alkalmazásban $=3 \mathrm{D}-2 \mathrm{D}$ Data Fusion in Cultural Heritage Applications ENELKO 2016. 17. Nemzetközi energetika-elektrotechnika konferencia: SzámOkt 2016 - 26. Nemzetközi számitástechnika és oktatás konferencia. Cluj-Napoca: EMT, 2016, p. 188-193. ISSN 1842-4546,

Gubo, Š. - Kmet', T. - Molnár. A. - Takáč, O. (2020): A Multi-range Approach for Cultural Heritage Survey: A Case Study of a Medieval Church in Slovakia / DOI 10.1109/ SAMI48414.2020.9108724. IEEE 18th World Symposium on Applied Machine Intelligence and Informatics: proceedings, Danvers: Institute of Electrical and Electronics Engineers, 2020, p. 117-122. SCOPUS. ISBN 978-1-7281-3149-8.

Hottenstein, J. (2015): Erosion and Soil. Feb 28, 2015. https://www.youtube.com/watch?v=im4HVXMGI68

ljiri T. - Todo H. - Hirabayashi A. - Kohiyama K. - Dobashi Y. (2018): Digitization of natural objects with micro CT and photographs, PLoS ONE 13(4): e0195852.DOI:10.1371/journal.pone.0195852 - 18 p.

Juhász Gy. (2011): A számítógépes molekulamodellezés helye a kémiatanár-képzésben. In: Természettudományok tanítása - korszerüen és vonzóan. Budapest: ELTE, 2011, p. 573-576. ISBN 978-963-284-224-0.

Juhász Gy. (2016): A számítógépes molekulamodellezés és a kémiai kötés elméletének oktatása. Györ: Palatia Nyomda és Kiadó, 2016, 116 p. ISBN 978-963-7692-78-9.

Juhász, J. - Matulík, D. (1999): Školské pokusy s počítačom. Aktuálne problémy vyučovania chémie na ZŠ a SŠ: Zborník z medzinárodnej konferencie. Bratislava: Štátny pedagogický ústav, 1999, p. 224-230. ISBN 80-85756-40-4.

Juhász, Gy. - Kysel', O. - Hegedűs, O. (2006): Molekulové modelovanie v príprave budúcich učitel'ov. In: Mezinárodní seminář - Soudobé trendy v chemickém vzdělávání. Hradec Králové: Univerzita Hradec Králové, 2006, p. 85-89. ISBN 80-7041-560-6.

Kirkby, M. J. (1987): Computer simulation in Physical geography. Chischester: Wiley, 47 p. Kiss, G. - Árki, Z. (2016): Comparison of the ICT literacy level of the Slovakian and Hungarian students in the higher education. DOI 10.1051/shsconf/20162601093 ERPA International Congresses on Education. Cedex a, France: E D P SCIENCES, 2016, Vol. 26 (2016), p. [1-9]. WoS.

Makádi M. - Horváth G. - Farkas B. P. (2013): Vizsgálati és bemutatási gyakorlatok a földrajztanításban. Budapest: Eötvös Loránd Tudományegyetem. Online: https://regi. tankonyvtar.hu/hu/tartalom/tamop412A/2011-0073_vizsgalati_bemutatasi_gyakorlatok_ foldrajztanitasban/index.html.

Mydlár, J. - Mydlárová Blaščáková, M. - Poráčová, J. - Zahatňanská, M. (2008): Utilization ICT in teaching and educating. In: Information and communication technology in natural science education - 2008: proceedings of international scientific practical conference. Šiauliai: Šiauliai University, 2008, p. 77-78. ISBN 978-9986-38-943-9.

Poráčová, J. - Zahatňanská, M. - Takaczova, M. - Mydlárová Blaščáková, M. (2008): Education software for biology teaching. In: Information and communication technology in natural science education - 2008: proceedings of international scientific practical conference. Šiauliai: Šiauliai University, 2008, p. 83-87. ISBN 978-9986-38-943-9.

Poráčová, J. - Nagy, M. - Mydlárová Blaščáková, M. - Sedlák, V. - Vašková, J. - Kotosová, J. - Pošiváková, T. - Konečná, M. - Frimmerová, A. (2014a): Cvičenia z fyziológie živočíchov a človeka. Prešov: FHPV PU v Prešove, 313 p. ISBN 978-80-555-1149-8.

Poráčová, J. - Nagy, M. - Bernátová, R. - Bernát, M. - Vaško, L. - Vašková, J. - Zahatňanská, M. - Mydlárová Blaščáková, M. - Sedlák, V. - Vadašová, B. - Kotosová, J. 
- Roháčová, T. - Pošiváková, T. - Konečná, M. - Frimmerová, A. (2014b): Fyziológia živočíchov a človeka. Prešov: Fakulta humanitných a prírodných vied PU v Prešove, 2014, 591 p. ISBN 978-80-555-1150-4.

Poráčová, J. - Nagy, M. - Mydlárová Blaščáková, M. - Sedlák, V. - Vašková, J. - Bernátová, R. - Vadašová, B. - Kimáková, T. - Lukáč, N. - Massányi, P. - Zahatňanská, M. - Kolesárová, A. - Odlerová, E. - Pošiváková, T. - Kotosová, J. - Frimmerová, A. (2015): Ekofyziológia živočíchov a človeka. Prešov: Prešovská Univerzita v Prešove, Fakulta humanitných a prírodných vied, 584 p. ISBN 978-80-555-1524-3.

Poráčová, J. - Nagy, M. - Vašková, J. - Vaško, L. - Mariychuk, R. - Zahatňanská, M. Mydlárová Blaščáková, M. - Konečná, M. - Grul'ová D. - Sedlák, V. - Avuková A. - Vašková H. (2021): General and applied biochemistry for natural sciences. Budapest: Budapest University of Technology and Economics, 2021, 225 p. ISBN 978-963-421-847-0.

Puskás, A. (2017): Motivational Strategies in English Teacher Training. In: Zborník medzinárodnej vedeckej konferencie Univerzity J. Selyeho - 2017: „Hodnota, kvalita a konkurencieschopnost' - výzvy 21. storočia" - Sekcie pedagogických vied. Komárno: Univerzita J. Selyeho, 2017, CD-ROM, p. 185-192. ISBN 978-80-8122-222-1.

Puskás, A. (2018a): Webové aplikácie v priprave budúcich učitel'ov cudzích jazykov. In: Inovácie v pregraduálnej príprave učitel'ov s využitím webových aplikácií. Komárom: KOMPRESS Nyomdaipari Kft., 2018, p. 51-62. ISBN 978-615-00-2597-1.

Puskás, A. (2018b): Using Information and Communication Technology in the Training of Future English Teachers. In: Zborník 10. medzinárodnej vedeckej konferencie Univerzity J. Selyeho - 2018. Komárno: Univerzita J. Selyeho, 2018, p. 49-55., CD-ROM. ISBN 978-80-8122-251-1.

Puskás, A. (2019): Higher education challenges: Improving cooperation and creativity by using drama techniques in EFL teacher training. In: IMCIC 19: The 10th International Multi-Conference on Complexity, Informatics and Cybernetics. Orlando: International Institute of Informatics and Systematics, 2019, p. 153-158. ISBN 978-1-941763-97-1. SCOPUS.

Takáč O. (2017): Modellezés és szimuláció. Komárno: Univerzita J. Selyeho, 2017, 235 p. ISBN 978-80-8122-203-0.

Takáč, O. (2020): Možnost' implementácie ochrany kultúrneho dedičstva do vyučovania informatiky. In: The Possibility of Implementing the Protection of Cultural Heritage in the Teaching of Informatics. Didinfo 2020: medzinárodní konference o vyučování informatiky: Medzinárodní konference o vyučování informatiky. Liberec: Technická univerzita v Liberci, 2020, p. 97-102. ISBN 978-80-7494-532-8. ISSN 2454-051X, online.

Takáč, O. - Végh, L. (2021a): Possibilities of Using Photogrammetry in the Teaching Process. 2021. In: EDULEARN21: 13th International Conference on Education and New Learning Technologies. 5th-6th July, 2021, p. 9237-9242. ISBN: 978-84-09-31267-2.

Takáč, O. - Végh, L. (2021b): Usage of Uavs in the Protection of Cultural Heritage in the Teaching of Computer Science. 2021. In: INTED2021: 15th International Technology, Education and Development Conference. 8th-9th March, 2021, p. 9987-9992. ISBN: 978-84-09-27666-0.

Zahatňanská, M. - Kušnírová, E. (2017): Metódy podporujúce aktívne vyučovanie. Prešov: Vydavatel'stvo Prešovskej univerzity, 2017, 178 p. ISBN 978-80-555-1959-3.

Zahatňanská, M. - Poráčová, J. - Roháčová, T. (2019): Požiadavky na učitel'a v informačnej spoločnosti. In: Vysokoškolské vzdelávanie v modernej spoločnosti: Vedecký medzinárodný recenzovaný zborník (eds. Daniela Hrehová, Gizela Brutovská, Václav Liška, Peter Gallo). Košice: Technická univerzita v Košiciach, 2019, p. 169-174. ISBN 978-80-5533517-9. 